to 1966 are covered, concerning populations of Eastern Asia and the Pacific; India, Tibet, Pakistan and Ceylon; the Middle East and Europe; North and West Africa; Central and East Africa, and the Americas, for a total of some 125 regions (listed in the Appendix).

Single chapters are devoted to population genetics and selection. The frequencies of abnormal hemoglobins are analyzed in their relation to malaria and interpreted in terms of selection pressures. The genetic theory of balanced polymorphism is further developed.

Well written and printed, although some goodwill is necessary for the interpretation of the geographical maps, this book may be recommended to geneticists, anthropologists and hematologists.

\section{Race and modern science}

By Robert E. Kuttner et al. Social Science Press - New York, 1967. Bound volume with jacket of XXX-427 pages. $15 \times 24 \mathrm{~cm}$. $\$ 7.95$.

Edited by Dr. Kuttner, this is a collection of essays by Anthropologists, Biologist, Sociologists and Psychologists. And it is accordingly divided into four parts.

Part One, on Anthropology, includes the following essays: Race and Anthropology, by B. Lundman; Morphology and the Classification of Race, by J. Czekanowski; Racial Biology of the Bantu of South Africa, by J. D. J. Hofmeyr; Race and the Biological History of Peoples, by I. Schwidetzky.

Part Two, on Biology, includes the following essays: A Study of Racial and Subracial Crossing, by L. Gedda; Race and Heredity, by D. C. Rife; The Races of Man and Human Genetics, by C. P. Oliver; Biochemical Anthropology, by R. E. Kuttner.

Part Three, on Sociology, includes the following essays: Human Society and Genetics, by C. D. Darlington; Race and Sociology, by C. Gini; Evolutionary Theory, Race and Society, by A. J. Gregor; Selective Association of Ethnic Groups, by G. A. Lundberg.

Part Four, on Psychology, includes the following essays: Race and Culture, by $\mathrm{F}$. Keiter; The Cultural Hypothesis and Psychological Tests, by F. C. J. McGurk; Racial Differences in School Achievement, by R. T. Osborne; Ethnic Groups and the Maze Test, by S. D. Porteus.

These sixteen essays by world's authorities in the various fields provide the book with an actual mine of information which may not only be precious to the specialist but also of interest to the layman.

Chemische Mutagenese an menschlichen Zellen in Kultur. (Chemical mutagenesis in human cells in culture)

By Wolfram Ostertag. Verlag der Akademie der Wissenschaften und der Literatur in Mainz (in Kommission bei Franz Steiner Verlag GMBH, Wiesbaden), 1966. 126 pages, including 34 figures and 32 tables; brochure; $18 \times 25 \mathrm{~cm}$. DM 12. ( $\$ 3.00$ approx.).

This booklet provides a historical sketch of research on mutation and a review of the present status and problems of experimental mutation induced chemically in mammalian and human cell cultures.

Actinomycin D, Proflavine and Anidine, Daunomycine and Cinerubine, Chromomycine $\mathrm{A}_{3}$, Terramycine, Ethylenimine and Mitomycine, Coffeine and Theophylline are among the principal substances studied in relation to their effects on cell morphology and physiology. Each review is completed by personal research.

This work may prove useful to all geneticists and cytologists interested in the problems of mutation and chemical agents.

\section{Intestinal absorption}

Edited by D. H. Smyth. London: British Med. ical Journal, 23:3, 1967, 95 pages; tables and illustrations; $28 \times 22 \mathrm{~cm}$. $£ 1.10$ ( $\$ 3.00$ approx.).

The various aspects of intestinal absorption, a subject of great present concern, are carefully examined in the following series of authoritative essays: 